\title{
Synthesis, structure and applications of [cis-dioxomolybdenum(VI)-(ONO)] type complexes
}

\author{
RAJAN DEEPAN CHAKRAVARTHY and DILLIP KUMAR CHAND* \\ Department of Chemistry, Indian Institute of Technology Madras, Chennai 600036, India \\ e-mail: dillip@iitm.ac.in
}

\begin{abstract}
Oxo-molybdenum chemistry is of great interest since such units are found in the active sites of a majority of molybdo-enzymes. In order to mimic the biological systems, a number of oxo-molybdenum complexes have been synthesised and studied. This review describes synthesis, structure and applications of oxomolybdenum complexes particularly cis $-\mathrm{MoO}_{2}(\mathbf{L})(\mathrm{D})$ where $\mathbf{L}$ stands for a dianionic tridentate ONO ligand and $\mathrm{D}$ for a donor solvent molecule/monodentate ligand. The ligand moieties are derived from Schiff base, hydrazide Schiff base and other related tridentate ligands $\mathbf{L}(\mathrm{H})_{2}$. The coordination geometry around the Mo center in these complexes can be best described as a distorted octahedron in which the ONO-tridentate ligand occupies meridional position with two anionic oxygen donors mutually trans and are cis to the oxygen centers of the cis-dioxo group. Mostly the applications of $c i s-\mathrm{MoO}_{2}-(\mathrm{ONO})$ type complexes seen in literature are oxo transfer reactions like epoxidation, sulfoxidation and phosphine oxidation reactions.
\end{abstract}

Keywords. Dioxomolybdenum(VI); ONO ligands; Oxo transfer reactions.

\section{Introduction}

Molybdenum has been found to be an important element in biological systems. It possesses a large number of stable and variable oxidation states as well as coordination numbers which can vary from four to eight. Although only a minor constituent of the earth's crust, molybdenum is readily available to biological systems because of the solubility of molybdate salts in water. Molybdenum is found in the active sites of enzymes such as nitrogenase, aldehyde oxidase, xanthine oxidase, sulfite oxidase, nitrate reductase and xanthine dehydrogenase. ${ }^{1}$ In contrast to the multinuclear iron- and molybdenum-containing centers in bacterial nitrogenases (responsible for fixing atmospheric nitrogen into the biosphere), the active sites of all other well-characterized molybdenum-containing enzymes are mononuclear. The vast majority of these enzymes possess at least one $\mathrm{Mo}=\mathrm{O}$ unit in their active sites and are often referred to as oxo-molybdenum enzymes. ${ }^{1}$ The fact that molybdenum-oxygen bonds are present in molybdo enzymes has stimulated research in molybdenum complexes with oxygen environments. In order to mimic the biological systems, a number of oxomolybdenum compounds have been synthesized and studied.

\footnotetext{
*For correspondence
}

Several industrial processes such as ammoxidation of olefins, ${ }^{2 a}$ olefin epoxidation ${ }^{2 b}$ and olefin metathesis $^{2 \mathrm{c}}$ are performed over molybdenum catalysts. The reactivity of selected cis-dioxomolybdenum(VI) compounds is recently reviewed by Jeyakumar and Chand, ${ }^{3}$ also by Sanz and Pedrosa. ${ }^{4}$ We have surveyed the literature on synthesis and reactivity of $\mathrm{Mo}(\mathrm{VI})$ ONO type complexes. In the year 1989 Syamal and Maurya published a review on Schiff base complexes of molybdenum ${ }^{5}$ which also accounted cisdioxomolybdenum(VI)-tridentate Schiff base ligands. This document covers the chemistry of several cisdioxomolybdenum complexes of dianionic tridentate ONO ligands, mostly Schiff bases, with particular emphasis on the recent progress.

\section{Synthesis and structure}

Schiff base ligands are typically prepared by the condensation of aldehydes or ketones with primary amines. These condensation reactions have been realized in different reaction conditions. The presence of a dehydrating agent e.g., $\mathrm{MgSO}_{4}$ normally favours the formation of Schiff bases. The water produced in the reaction can also be removed by azeotropic distillation with toluene or benzene. Methanol or ethanol is also used as solvents for the preparation of Schiff base ligands. Condensation 


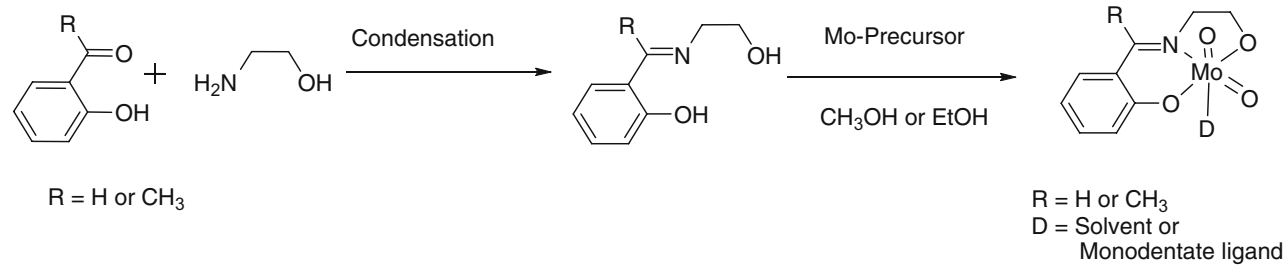

Scheme 1. Synthesis of cis-dioxomolybdenum(VI) Schiff base complexes.

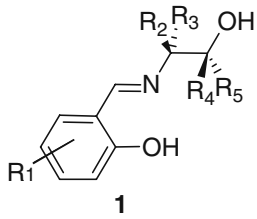

1a $\mathrm{R}_{1}=\mathrm{H} \quad \mathrm{R}_{2}=\mathrm{R}_{3}=\mathrm{R}_{4}=\mathrm{R}_{5}=\mathrm{H}(9,10,33)$

1b $\mathrm{R}_{1}=5-\mathrm{C}_{4} \mathrm{H}_{9} \mathrm{R}_{2}=\mathrm{R}_{3}=\mathrm{R}_{4}=\mathrm{R}_{5}=\mathrm{H}$ (9)

1c $\mathrm{R}_{1}=5-\mathrm{CH}_{3} \quad \mathrm{R}_{2}=\mathrm{R}_{3}=\mathrm{R}_{4}=\mathrm{R}_{5}=\mathrm{H}$ (9)

1d $\mathrm{R} 1=5-\mathrm{Br} \quad \mathrm{R}_{2}=\mathrm{R}_{3}=\mathrm{R}_{4}=\mathrm{R}_{5}=\mathrm{H}(10)$

1e $\mathrm{R}_{1}=5-\mathrm{Cl} \quad \mathrm{R}_{2}=\mathrm{R}_{3}=\mathrm{R}_{4}=\mathrm{R}_{5}=\mathrm{H}(10)$

If $\quad \mathrm{R}_{1}=5-\mathrm{NO}_{2} \quad \mathrm{R}_{2}=\mathrm{R}_{3}=\mathrm{R}_{4}=\mathrm{R}_{5}=\mathrm{H}$ (10)

1g $\mathrm{R}_{1}=5-\mathrm{CH}_{3} \mathrm{O} \quad \mathrm{R}_{2}=\mathrm{R}_{3}=\mathrm{R}_{4}=\mathrm{R}_{5}=\mathrm{H}(10)$

1h $\mathrm{R}_{1}=\mathrm{H} \quad \mathrm{R}_{2}=\mathrm{C}_{4} \mathrm{H}_{5} \mathrm{~N}_{2} \mathrm{R}_{3}=\mathrm{R}_{4}=\mathrm{R}_{5}=\mathrm{H}$ (13)

1i $\quad \mathrm{R}_{1}=3-\mathrm{CH}_{3} \mathrm{O} \quad \mathrm{R}_{2}=\mathrm{R}_{3}=\mathrm{CH}_{3} \mathrm{R}_{4}=\mathrm{R}_{5}=\mathrm{H}(18,29)$

1j $\mathrm{R}_{1}=\mathrm{H} \quad \mathrm{R}_{2}=\mathrm{CH}_{2} \mathrm{OH} \mathrm{R} \mathrm{R}_{3}=\mathrm{CH}_{3} \mathrm{R}_{4}=\mathrm{R}_{5}=\mathrm{H}$ (18)

1 k $\mathrm{R}_{1}=3-\mathrm{CH}_{3} \mathrm{O} \quad \mathrm{R}_{2}=\mathrm{CH}_{2} \mathrm{OH} \mathrm{R} \mathrm{R}_{3}=\mathrm{CH}_{3} \mathrm{R}_{4}=\mathrm{R}_{5}=\mathrm{H}(18)$

1I $\mathrm{R}_{1}=\mathrm{H} \quad \mathrm{R}_{2}=\mathrm{R}_{3}=\mathrm{CH}_{2} \mathrm{OH} \mathrm{R} \mathrm{R}_{4}=\mathrm{R}_{5}=\mathrm{H}(18,22,49)$

$1 \mathrm{~m} \mathrm{R} 1=3-\mathrm{CH}_{3} \mathrm{O} \quad \mathrm{R}_{2}=\mathrm{R}_{3}=\mathrm{CH}_{2} \mathrm{OH} \mathrm{R} \mathrm{R}_{4}=\mathrm{R}_{5}=\mathrm{H}$ (18)

1n $\mathrm{R}_{1}=\mathrm{H} \quad \mathrm{R}_{2}=\mathrm{C}_{2} \mathrm{H}_{5} \mathrm{R}_{3}=\mathrm{CH}_{2} \mathrm{OH} \mathrm{R} \mathrm{R}_{4}=\mathrm{R}_{5}=\mathrm{H}$ (49)

10 $R_{1}=H \quad R_{2}=R_{3}=C_{3} R_{4}=R_{5}=H(18,19,20,29)$

1p $\mathrm{R}_{1}=\mathrm{H} \quad \mathrm{R}_{2}=\mathrm{H} \mathrm{R}_{3}=\mathrm{C}_{2} \mathrm{H}_{5} \mathrm{R}_{4}=\mathrm{R}_{5}=\mathrm{H}(20)$

$1 q \mathrm{R}_{1}=\mathrm{H} \quad \mathrm{R}_{2}=\mathrm{CH}_{3} \mathrm{R}_{3}=\mathrm{CH}_{2} \mathrm{OH} \mathrm{R} \mathrm{R}_{4}=\mathrm{R}_{5}=\mathrm{H}(20,21,49)$

1r $\mathrm{R}_{1}=\mathrm{H} \quad \mathrm{R}_{2}=\mathrm{CH}_{2} \mathrm{OH} \mathrm{R} \mathrm{R}_{3}=\mathrm{H} \mathrm{R}_{4}=\mathrm{H} \mathrm{R}_{5}=\mathrm{C}_{6} \mathrm{H}_{5}(20,21)$

1s $\mathrm{R}_{1}=\mathrm{H} \quad \mathrm{R}_{2}=\mathrm{CH}_{3} \mathrm{R}_{3}=\mathrm{H} \mathrm{R}_{4}=\mathrm{C}_{6} \mathrm{H}_{5} \mathrm{R}_{5}=\mathrm{H}(21)$

1t $\mathrm{R}_{1}=3-\mathrm{OH} \quad \mathrm{R}_{2}=\mathrm{R}_{3}=\mathrm{CH}_{2} \mathrm{OH} \mathrm{R} \mathrm{R}_{4}=\mathrm{R}_{5}=\mathrm{H}(22)$

1u $\mathrm{R}_{1}=3,4-\mathrm{OH} \quad \mathrm{R}_{2}=\mathrm{R}_{3}=\mathrm{CH}_{2} \mathrm{OH} \mathrm{R}_{4}=\mathrm{R}_{5}=\mathrm{H}$ (22)

1v $\mathrm{R}_{1}=3-\mathrm{C}_{2} \mathrm{H}_{5} \mathrm{OR}=\mathrm{R}_{3}=\mathrm{CH}_{2} \mathrm{OH} \mathrm{R} \mathrm{R}_{4}=\mathrm{R}_{5}=\mathrm{H}(24)$

1w $\mathrm{R}_{1}=5-\mathrm{NO}_{2} \quad \mathrm{R}_{2}=\mathrm{R}_{3}=\mathrm{CH}_{2} \mathrm{OH} \mathrm{R} \mathrm{R}_{4}=\mathrm{R} 5=\mathrm{H}(24)$

$1 x \quad \mathrm{R}_{1}=\mathrm{H} \quad \mathrm{R}_{2}=\mathrm{R}_{3}=\mathrm{R}_{4}=\mathrm{H} \mathrm{R}_{5}=\mathrm{CH}_{3}$ (25)

1y $\mathrm{R}_{1}=3-\mathrm{CH}_{3} \mathrm{O} \mathrm{R}_{2}=\mathrm{R}_{3}=\mathrm{R}_{4}=\mathrm{R}_{5}=\mathrm{H}$ (33)

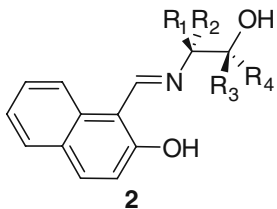

2a $R_{1}=R_{2}=R_{3}=R_{4}=H(33,9)$

2b $\mathrm{R}_{1}=\mathrm{R}_{3}=\mathrm{R}_{4}=\mathrm{H} \mathrm{R}_{2}=\mathrm{C}_{2} \mathrm{H}_{5}$ (16)

2c $\mathrm{R}_{1}=\mathrm{CH}_{2} \mathrm{OH} \mathrm{R} \mathrm{R}_{2}=\mathrm{CH}_{3} \mathrm{R}_{3}=\mathrm{R}_{4}=\mathrm{H}$ (18)

2d R $\mathrm{R}_{1}=\mathrm{R}_{2}=\mathrm{CH}_{2} \mathrm{OH} \mathrm{R} \mathrm{R}_{3}=\mathrm{R}_{4}=\mathrm{H}(18,24)$

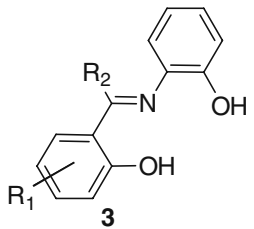

3a $\mathrm{R}_{1}=\mathrm{H} \mathrm{R}_{2}=\mathrm{H}(9)$

3b $\mathrm{R}_{1}=5-\mathrm{CH}_{3} \mathrm{R}_{2}=\mathrm{H}(9)$

3c $\mathrm{R}_{1}=5-\mathrm{C}_{4} \mathrm{H}_{9} \mathrm{R}_{2}=\mathrm{H}(9,14)$

3d $\mathrm{R}_{1}=5,6-\mathrm{C}_{4} \mathrm{H}_{4} \mathrm{R}_{2}=\mathrm{H}(9)$

3e $\mathrm{R}_{1}=5-\mathrm{NO}_{2} \mathrm{R}_{2}=\mathrm{H}(7)$

3f $\mathrm{R}_{1}=5-\mathrm{Br} \mathrm{R} \mathrm{R}_{2}=\mathrm{H}(7)$

3 g $\mathrm{R}_{1}=5-\mathrm{CH}_{3} \mathrm{O} \mathrm{R} \mathrm{R}_{2}=\mathrm{H}(7)$

3h $\mathrm{R}_{1}=3-\mathrm{C}_{4} \mathrm{H}_{9} \mathrm{R}_{2}=\mathrm{H}$ (9)

3i $\quad \mathrm{R}_{1}=5-\mathrm{Cl} \mathrm{R} \mathrm{R}_{2}=\mathrm{H}(10)$

3j $\mathrm{R}_{1}=\mathrm{H} \mathrm{R}_{2}=\mathrm{CH}_{3}$ (8)

3k $\mathrm{R}_{1}=5-\mathrm{CH}_{3} \mathrm{R}_{2}=\mathrm{CH}_{3}(9)$

31 $\mathrm{R}_{1}=5-\mathrm{C}_{4} \mathrm{H}_{9} \mathrm{R}_{2}=\mathrm{CH}_{3}(9)$<smiles>[R6]C(=NC([R5])c1ccccc1O)c1ccccc1O</smiles>

4

4a $\mathrm{R}_{1}=\mathrm{H} \mathrm{R}_{2}=\mathrm{H} \mathrm{R}_{3}=\mathrm{H}(11,17)$

4b $\mathrm{R}_{1}=5,6-\mathrm{C}_{4} \mathrm{H}_{4} \mathrm{R}_{2}=\mathrm{H} \mathrm{R}_{3}=\mathrm{H}(11,17)$

4c $\mathrm{R}_{1}=\mathrm{H} \mathrm{R}_{2}=\mathrm{CH}_{3} \mathrm{R}_{3}=\mathrm{H}$ (11)

4d $\mathrm{R}_{1}=\mathrm{H} \mathrm{R}_{2}=\mathrm{CH}_{3} \mathrm{R}_{3}=\mathrm{CH}_{3}$ (11)

4e $\mathrm{R}_{1}=5,6-\mathrm{C}_{4} \mathrm{H}_{4} \mathrm{R}_{2}=\mathrm{CH}_{3} \mathrm{R}_{3}=\mathrm{H}$ (11)

$4 f \mathrm{R}_{1}=5,6-\mathrm{C}_{4} \mathrm{H}_{4} \mathrm{R}_{2}=\mathrm{CH}_{3} \mathrm{R}_{3}=\mathrm{CH}_{3}(11)$

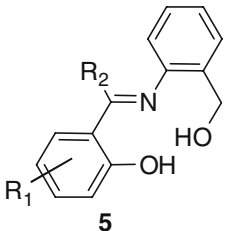

5a $\mathrm{R}_{1}=\mathrm{H} \mathrm{R} \mathrm{R}_{2}=\mathrm{H}(12,33)$

5b $\mathrm{R}_{1}=\mathrm{H} \mathrm{R}_{2}=\mathrm{CH}_{3}(11)$

5c $\mathrm{R}_{1}=5,6-\mathrm{C}_{4} \mathrm{H}_{4} \mathrm{R}_{2}=\mathrm{H}(12,33)$

5 d $\mathrm{R}_{1}=5,6-\mathrm{C}_{4} \mathrm{H}_{4} \mathrm{R}_{2}=\mathrm{CH}_{3}(11)$

5e $\mathrm{R}_{1}=3-\mathrm{CH}_{3} \mathrm{O} \mathrm{R} \mathrm{R}_{2}=\mathrm{H}$ (33)

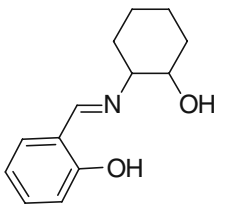

$6(23)$<smiles>[Z19]c1ncc(CO)c(/C=N/c2ccccc2O)c1O</smiles>

$7(11)$<smiles>Cc1ncc(CO)c(/N=C/c2ccccc2CO)c1O</smiles>

8 (11)

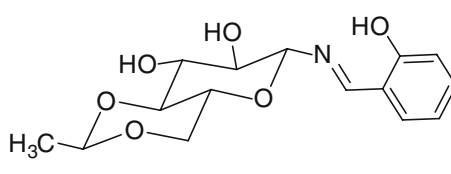

9 (31)<smiles>[R]c1ccc(O)c(C=N)c1</smiles><smiles>[R]OCC1(CO[R])O[C@@H](O)C(N)C1[R]</smiles>

10a $R=H^{10} R^{\prime}=H(32)$ $10 \mathrm{~b} R=A c R^{\prime}=H^{(32)}$ 10c $R=A c R^{\prime}=5-C l(32)$

Figure 1. Various ONO type Schiff base ligands $\mathbf{L}(\mathrm{H})_{2}$ used for the preparation of cis-dioxomolybdenum(VI) complexes $\left[\right.$ cis- $\left.\mathrm{MoO}_{2}(\mathbf{L})(\mathrm{D})\right]$ (reference numbers are given in brackets).

of salicylaldehyde or its derivatives with amino-alcohol or amino-phenol results in the formation of a Schiff base ligands, $\mathbf{L}(\mathrm{H})_{2}$. A general scheme for the synthesis of a majority of the cis- $\mathrm{MoO}_{2}(\mathrm{ONO})$ type complexes, is shown in scheme 1 and more examples are included in figure $1 .^{6-33}$ This family of complexes, introduced by Rajan and Chakravorty, ${ }^{6,9}$ has been prepared by reacting Schiff bases with suitable molybdenum 


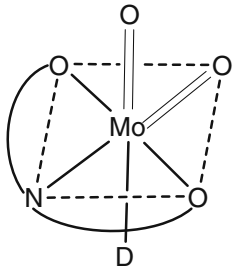

Monomer

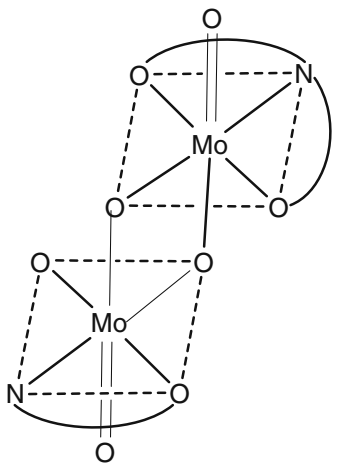

Dimer

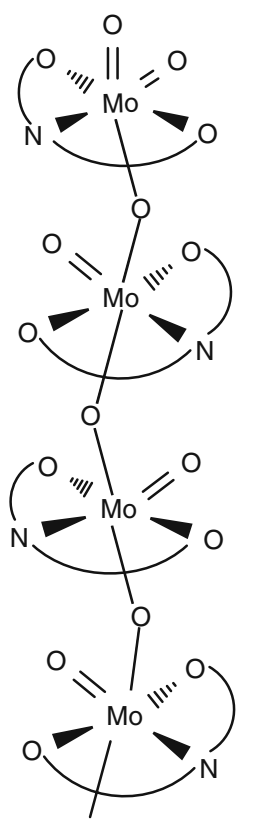

Linear polymer
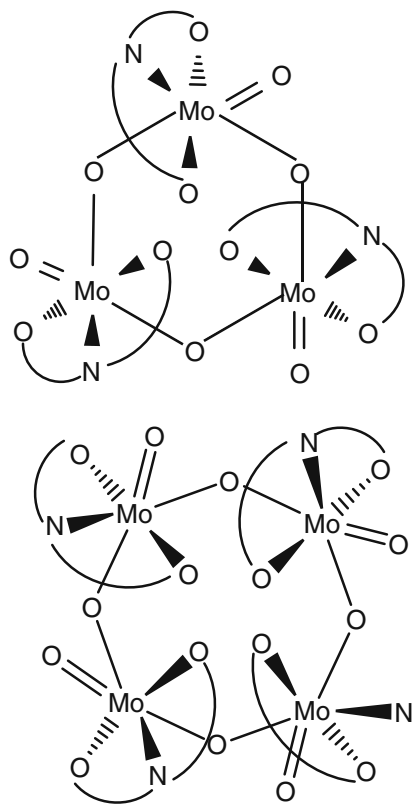

Cyclic polymer

Figure 2. Coordination geometry of monomeric, dimeric, and oligomeric Mo(VI) complexes.

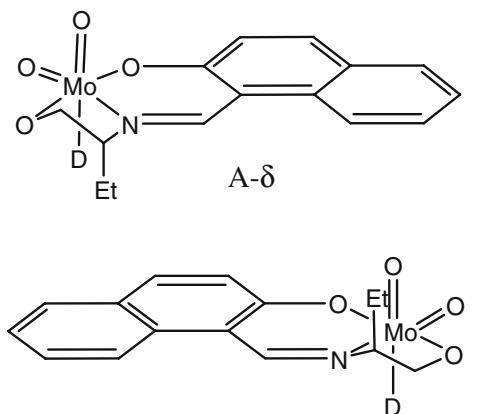

B- $\delta$
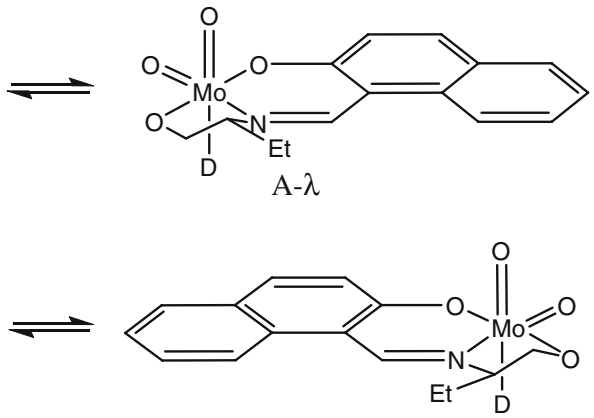

$\mathrm{B}-\lambda$

Scheme 2. The isomers suggested due to conformational changes (i.e., A- $\delta$, $\mathrm{A}-\lambda, \mathrm{B}-\delta$ and $\mathrm{B}-\lambda)$ of a monomeric $\mathrm{Mo}(\mathrm{VI})$ complex.

precursors such as $\mathrm{MoO}_{2}(\mathrm{acac})_{2}, \mathrm{MoO}_{2}(\mathrm{sal})_{2}$, molybdates or molybdenum dichloride dioxide in alcohol.

Molecular formula of these complexes can be represented as $\left[\right.$ cis- $\left.\mathrm{MoO}_{2}(\mathbf{L})(\mathrm{D})\right]$ where $\mathbf{L}$ stands for a dianionic tridentate ligand and $\mathrm{D}$ for a donor solvent molecule/monodentate ligand. Dioxomolybdenum complexes of comparable types have also been prepared with Schiff bases derived from $o$-hydroxyacetophenone and derivatives. ${ }^{6-33}$ Depending on the method of preparation, molybdenum precursor of choice and reaction conditions, the complexes synthesized with dianionic tridentate ligands are of the following types: monomeric $\left[\right.$ cis $\left.-\mathrm{MoO}_{2}(\mathbf{L})(\mathrm{D})\right]$, which is dominant, or dimeric $\left[(\mathrm{MoO}(\mu-\mathrm{O})(\mathbf{L}))_{2}\right]$ with asymmetric double oxygen bridge, or polymeric with single oxygen bridge (figure 2). The coordination geometry around the Mo center in a mononuclear complex can be best described as a distorted octahedron in which the ONO-tridentate ligand occupies meridional position with two anionic oxygen donors mutually trans and are cis to the oxygen centers of the cis-dioxo group (figure 2). The usual octahedral geometry of a molybdenum center is 

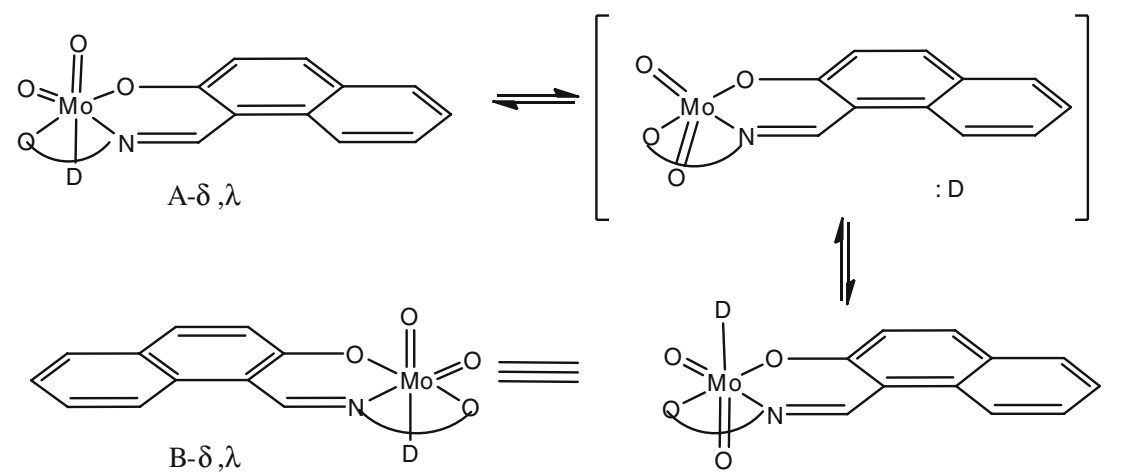

Scheme 3. Proposed pathway showing inter-conversion of the isomers A and B.

additionally completed by a coordinated solvent molecule or monodentate neutral ligand (D). The labile coordination site of molybdenum occupied by $\mathrm{D}$ allows favourable uptake and activation of substrates during the Lewis acid catalysed transformations. However, this site can also be responsible for dimerization and oilgomerization/polymerization of mononuclear complexes. The coordination polymer of a polynuclear dioxomolybdenum(VI) complexes generally exhibits a linear $\mathrm{Mo}=\mathrm{O} \cdots \mathrm{Mo}=\mathrm{O} \cdots$ chain where the axial oxo-ligand participates in bridging. The arrangement gives rise to a structure where one $(\mathrm{MoO}(\mu-\mathrm{O})(\mathbf{L}))$ unit coordinates to the sixth site of the molybdenum atom of an adjacent unit. Tri/tetranuclear cyclic structures having three/four such units cyclised to give six/eight-membered rings or even higher nuclearity cyclic structures are also known. ${ }^{29}$

The mononuclear complexes exhibit two stretching frequencies $[v(\mathrm{O}=\mathrm{Mo}=\mathrm{O})]$ in the region 910 $950 \mathrm{~cm}^{-1}$ and $890-925 \mathrm{~cm}^{-1}$ indicating the presence of cis- $\mathrm{MoO}_{2}$ fragment. However, oligomeric compounds show only one $v(\mathrm{Mo}=\mathrm{O})$ vibrational stretching frequency in the region $930 \mathrm{~cm}^{-1}$ and a strong characteristic band around $800 \mathrm{~cm}^{-1}$ due to $\mathrm{Mo}=\mathrm{O} \cdots \mathrm{Mo}=\mathrm{O} \cdots$ interaction. Thus, IR spectroscopy can be used to distinguish an oligomeric complex from a monomeric complex. ${ }^{9}$

The oligomers react with a wide variety of unidentate neutral ligands, (D) such as aldehydes, amides, amines, sulfoxides, phosphine oxides, water, alcohols and phosphines to form mononuclear complexes. Further, the mononuclear molybdenum complexes can undergo ligand substitution reactions where (D) can be substituted by $\left(\mathrm{D}^{\prime}\right)$ as shown in equation 1 .

$$
c i s-\mathrm{MoO}_{2}(L)(\mathrm{D})+\mathrm{D}^{\prime} \longrightarrow \text { cis }-\mathrm{MoO}_{2}(L)\left(\mathrm{D}^{\prime}\right)+\mathrm{D} .
$$

On the basis of ligand displacement reactions, the binding of some $\mathrm{D}$ (or $\mathrm{D}^{\prime}$ ) increases in the order of acetaldehyde $<$ benzaldehyde $<$ ethanol $<$ anisaldehyde $<$ dimethylformamide $<$ picoline $<$ dimethyl sulfoxide $<$ imidazole $<$ pyridine- $N$-oxide. ${ }^{9}$ The complexes are found to be non-electrolyte and diamagnetic as expected for a $4 d^{0}$ system, however, ligand to metal charge transfer (LMCT) band can be seen in the electronic spectrum. ${ }^{7,10}$

Nakajima et al. have discussed structural properties of a monomeric complex in the solid and solution states. ${ }^{16}$ The cis-dioxomolybdenum(VI) complex of the chiral Schiff base ligand, $2 \mathbf{b}$ derived from 2-hydroxy-1-naphthaldehyde and $(R)$-2-aminobutanol can potentially give four possible isomeric structures i.e., $\mathrm{A}-\delta, \mathrm{A}-\lambda, \mathrm{B}-\delta$ and $\mathrm{B}-\lambda$ due to the conformational changes of the non-planar five-member ring as shown in scheme 2.

Observation of only one set of signals in the proton NMR spectrum of the complex, even at low temperature, suggests rapid exchange of the isomers in NMR time scale. However, the X-ray crystal structure revealed the existence of the $\mathrm{A}-\delta$ isomer, in solid state. Fast puckering of the conformation of the chelate
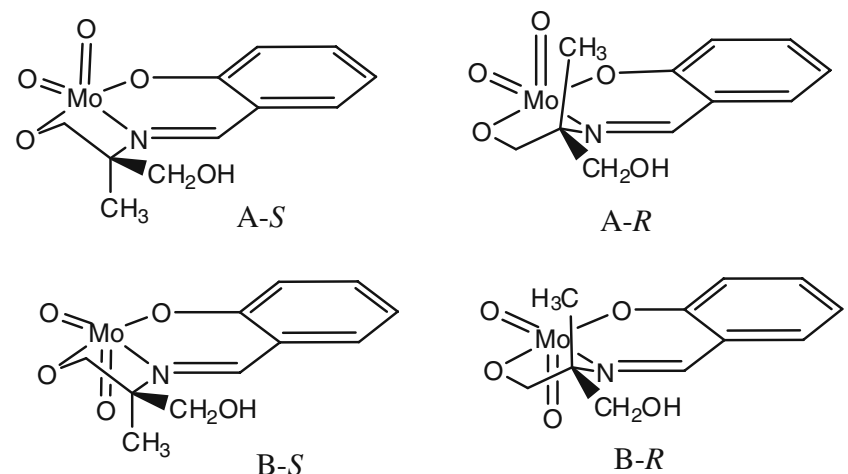

Figure 3. Four isomers of the monomeric complex generated from a prochiral ligand. The complex $\mathrm{B}-R$ is the mirror image of $\mathrm{A}-S$, and $\mathrm{B}-S$ is the mirror image of $\mathrm{A}-R$. 


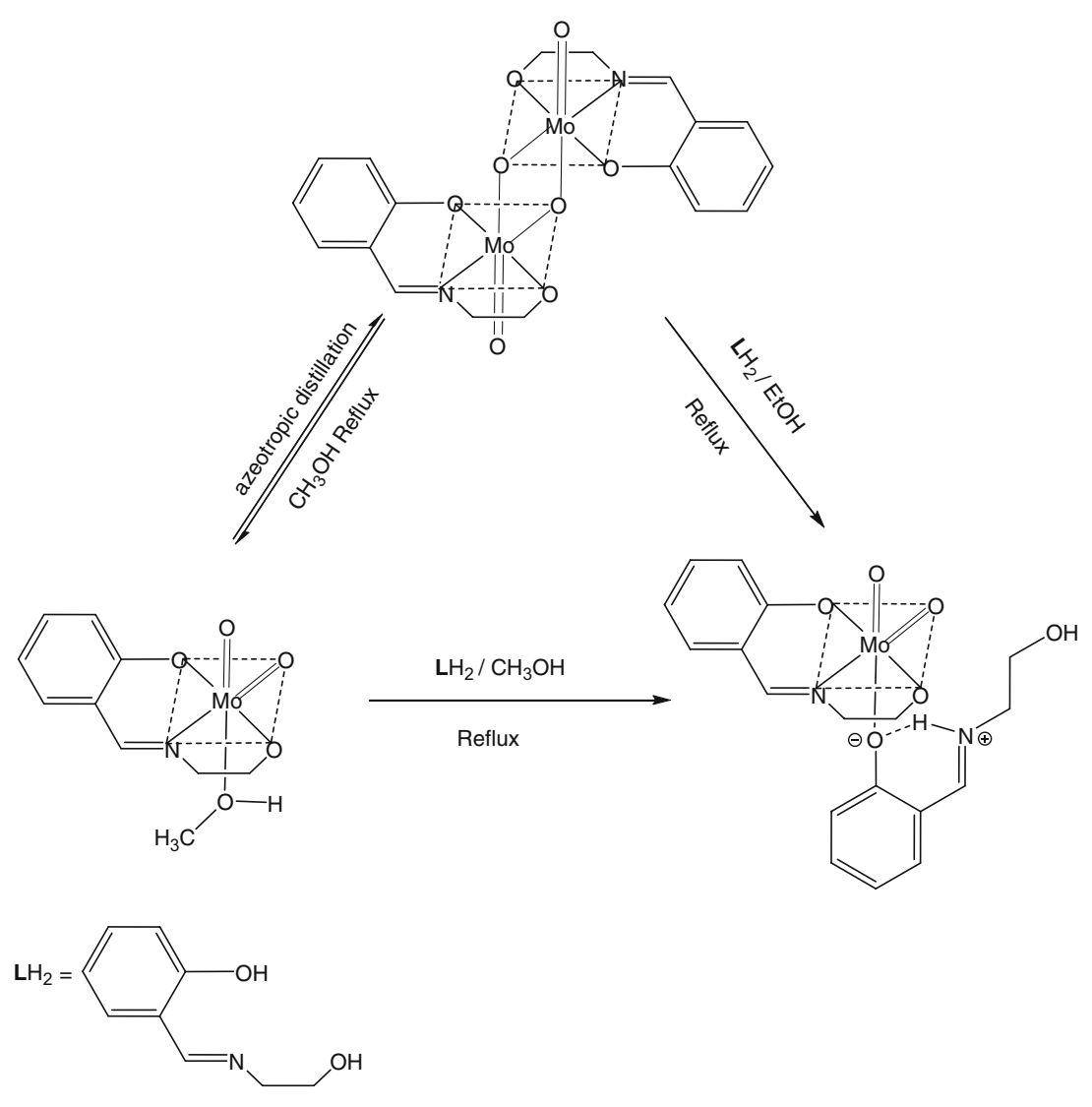

Scheme 4. Selective synthesis of monomeric and dimeric Mo(VI) complexes.

ring of aminoalcohol moiety is suggested as a factor responsible for the dynamic equilibrium between $\delta$ and $\lambda$ isomers. Inter-conversion between the isomers $\mathrm{A}$ and B would also proceed by dissociation of monodentate ligand followed by rotation of cis-dioxo moiety and recoordination of the ligand (scheme 3).

On the other hand, prochiral Schiff base ligand, 1q derived from salicylaldehyde and 2-amino-2-methyl1,3-propanediol becomes chiral upon coordination to form the Mo(VI) complex (figure 3). ${ }^{21}$

Głowiak and coworkers reported an independent method for the synthesis of monomeric and dimeric complexes (scheme 4). ${ }^{30}$ A monomeric complex containing one extra zwitterionic ligand is also prepared. The authors suggested that the formation of different dioxomolybdenum(VI) complexes mainly depend on the basicity of the nitrogen atom of the Schiff base, synthetic methodology and reaction conditions.

The formation of monomeric and dimeric Mo(VI) complexes based on solvent effect and its interconversion in cases of a tridentate amino-bisphenol ligand system (scheme 5) is explained by Lehtonen et $a .^{34}$ Reaction of the tridentate ligand with $\mathrm{MoO}_{2}(\mathrm{acac})_{2}$ in methanol leads to the formation of

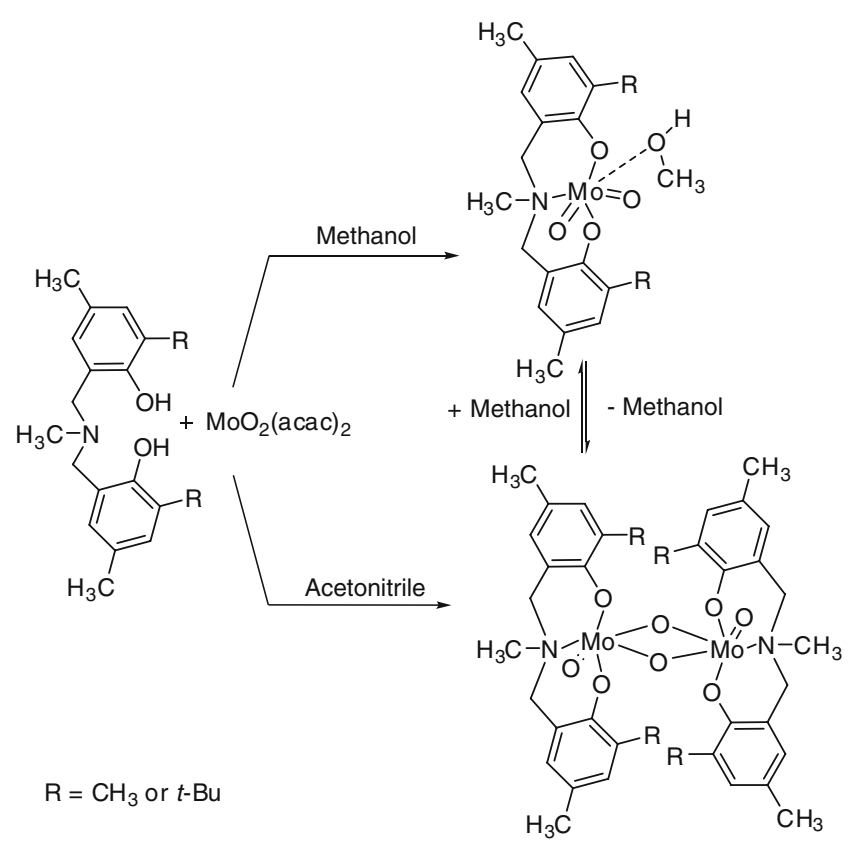

Scheme 5. Formation of monomeric and dimeric Mo(VI) complexes of a tridentate amino-bisphenolate ligand. 


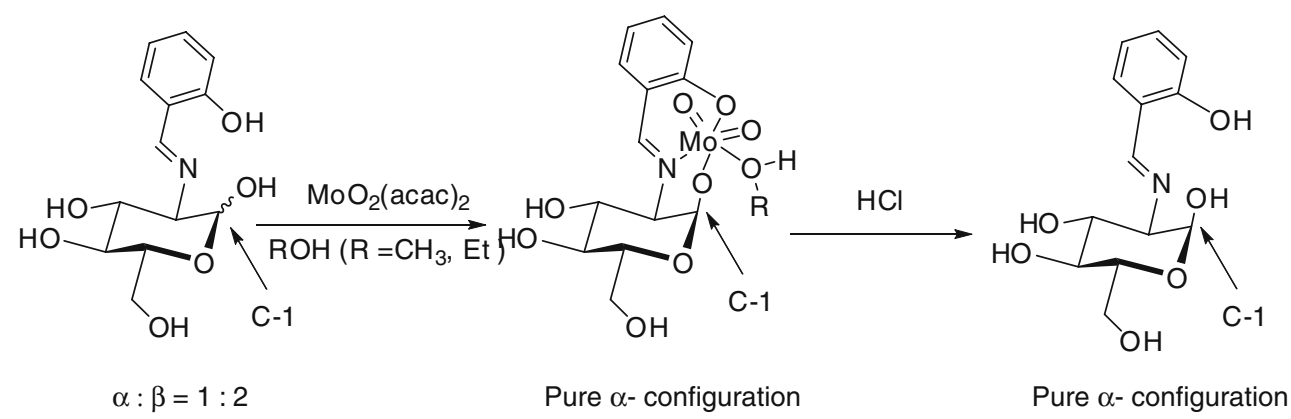

Scheme 6. Synthesis of a Mo(VI) Schiff base complexe by selective inversion at C-1 carbon of a sugar-based ligand.

monomeric dioxomolybdenum(VI) complexes of general formula $\left[c i s-\mathrm{MoO}_{2}(\mathbf{L})\left(\mathrm{CH}_{3} \mathrm{OH}\right)\right]$. Similar reaction in acetonitrile solvent leads to dimeric dioxomolybdenum(VI) complexes of formula $\left[(\mathrm{MoO}(\mu-\mathrm{O})(\mathbf{L}))_{2}\right]$ (scheme 5). The mononuclear complex undergoes slow dimerization when suspended in acetonitrile or kept under vacuum. Similarly, the dimeric complexes when recrystallised from methanol gave monomeric complex.

Molybdenum(VI) complexes bearing sugar derived chiral Schiff base ligands of general molecular formula cis $-\mathrm{MoO}_{2}(\mathbf{L})(\mathrm{D})$ have been prepared using the sugar-based ligand 10a and $\mathrm{MoO}_{2}(\mathrm{acac})_{2} \cdot{ }^{32}$ The complexation reaction leads to the inversion at $\mathrm{C}-1$ carbon atom of the glucose ring in order to reach the optimal coordination geometry (scheme 6).

The ligand 10b was prepared by acetylation of 10a where upon all the alcohol groups of the sugar-based chiral ligand are protected. When complexation was performed using $10 \mathrm{~b}$ the Lewis acid catalysed deacetylation followed by selective inversion at $\mathrm{C}-1$ center of the glucose ring was observed (scheme 7).

Hydrazide Schiff base ligands are also examples of dianionic tridentate ligands (figure 4). The Schiff base ligands produced from salicylaldehyde and appropriate hydrazide form aquo complexes of the type $\left[\right.$ cis- $\left.\mathrm{MoO}_{2}(\mathbf{L})(\mathrm{D})\right]$ (where, $\mathbf{L}$ is a dianionic tridentate

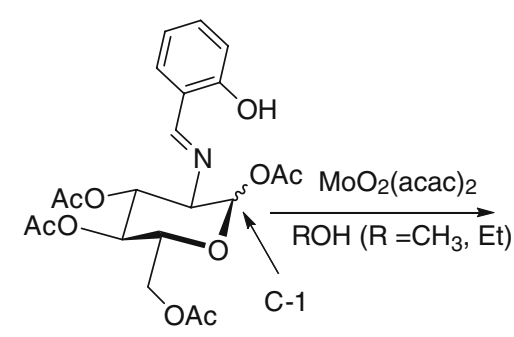

$\alpha$-configuration at $\mathrm{C}$-1 $\beta$-configuration at $\mathrm{C}$-1

Scheme 7. Synthesis of Mo(VI) Schiff base complexes by deacetylation followed selective inversion at $\mathrm{C}-1$ carbon of a sugar-based ligand. ligand and $\mathrm{D}$ is water) with ammonium molybdate as shown in equation 2 . These aquo complexes are generally prepared by reacting dilute sulfuric acid solution of ammonium or sodium molybdate with dilute sodium hydroxide solution of selected Schiff base at $\mathrm{pH} 6 .{ }^{35-38}$

$$
\begin{aligned}
& \left(\mathrm{NH}_{4}\right)_{2} \mathrm{MoO}_{4}+\mathbf{L H}_{2} \\
& \underset{\mathrm{pH} 6}{\stackrel{\mathrm{H}_{2} \mathrm{SO}_{4}}{\longrightarrow}}\left[\mathrm{MoO}_{2}(\mathbf{L})\left(\mathrm{H}_{2} \mathrm{O}\right)\right]+\left(\mathrm{NH}_{4}\right)_{2} \mathrm{SO}_{4} .
\end{aligned}
$$

Similarly, the solvent coordinated complexes can be prepared by ligand exchange reactions of Schiff base ligands with $\mathrm{MoO}_{2}(\mathrm{acac})_{2}$ in alcohol as shown in scheme $8 .^{38-42}$

The shift of IR band due to $\mathrm{C}=\mathrm{N}$ towards lower energy by $10-30 \mathrm{~cm}^{-1}$ in these complexes as compared to the free Schiff base value of $1620-1640 \mathrm{~cm}^{-1}$ suggest the coordination of azomethine nitrogen to molybdenum center. Further, disappearance of the band due to $\mathrm{C}=\mathrm{O}$ around $1640-1655$ present in free Schiff bases indicates the destruction of carbonyl moiety due to enolisation. Thus, the IR data indicate that the Schiff bases behave as tridentate ligands coordinating through phenolic oxygen, enolic oxygen and azomethine nitrogen. ${ }^{35-42}$ The coordination geometry around molybdenum can also be described as distorted octahedral in which the dianionic ligand is ligated in a planar tridentate manner forming one five-membered and another six-membered metallocycle involving cisdioxomolybdenum moiety.

Some other variety of ONO ligands (figure 5) are also employed to prepare analogues complexes. Dioxomolybdenum(VI) dipicolinate complexes have been reported using ligand 19 which was prepared by reacting equimolar amount of dipicolinate with DMF or DMSO adducts of $\mathrm{MoO}_{2} \mathrm{Cl}_{2}$, followed by addition of appropriate ligand $^{43}$ (scheme 9).

Barbaro et al. reported oligomeric complexes containing $\mathrm{MoO}_{2}(\mathbf{L})$ units which could be prepared from complexation of chiral amino diols containing three asymmetric centers with $\mathrm{MoO}_{2}(\mathrm{acac})_{2}$ (scheme 10). ${ }^{44}$ 
<smiles>[R]C(=NNC(=O)c1ccc(Br)cc1O)c1ccccc1</smiles>

11

11a $\mathrm{R}_{1}=\mathrm{H} \mathrm{R}_{2}=\mathrm{H}$ (38)

11b $\mathrm{R}_{1}=\mathrm{H} \mathrm{R}_{2}=\mathrm{CH}_{3}$ (37)

11c $\mathrm{R}_{1}=5,6-\mathrm{C}_{4} \mathrm{H}_{4} \mathrm{R}_{2}=\mathrm{H}$ (38)

11d $\mathrm{R}_{1}=5,6-\mathrm{C}_{4} \mathrm{H}_{4} \mathrm{R}_{2}=\mathrm{CH}_{3}$ (38)<smiles>[R]C(=NNC(=O)c1ccccn1)c1ccc(Br)cc1O</smiles>

15a $\mathrm{R}_{1}=\mathrm{H} \mathrm{R}_{2}=\mathrm{H}$ (37)

15b R $\mathrm{R}_{1}=\mathrm{H} \mathrm{R}_{2}=\mathrm{CH}_{3}$ (37)

15c $\mathrm{R}_{1}=5,6-\mathrm{C}_{4} \mathrm{H}_{4} \mathrm{R}_{2}=\mathrm{H}$ (37)<smiles>[R]C(=NNC(=O)c1cccc(C)c1O)c1ccc(Br)cc1O</smiles>

12

12a $R_{1}=H R_{2}=H$ (38) 12b $\mathrm{R}_{1}=\mathrm{H} \mathrm{R}_{2}=\mathrm{CH}_{3}$ (38) 12c $\mathrm{R}_{1}=5,6-\mathrm{C}_{4} \mathrm{H}_{4} \mathrm{R}_{2}=\mathrm{H}$ (38)<smiles>[R]c1ccc(/C=N/NC(=O)c2ccccc2O)c(O)c1</smiles>

13a $\mathrm{R}=\mathrm{HX}=\mathrm{S}$ (38)

13b $\mathrm{R}=5,6-\mathrm{C}_{4} \mathrm{H}_{4} \mathrm{X}=\mathrm{S}$ (38)

13c $\mathrm{R}=\mathrm{HX}=\mathrm{O}$ (38)

13d $\mathrm{R}=5-\mathrm{CIX}=\mathrm{O}(38)$

13e $\mathrm{R}=5-\mathrm{BrX}=\mathrm{O}$ (38)

13f $\mathrm{R}=5-\mathrm{NO}_{2} \mathrm{X}=\mathrm{O}$ (38)

13g R=5- $\mathrm{C}_{2} \mathrm{H}_{5} \mathrm{OX}=\mathrm{O}$ (38)

13h $\mathrm{R}=5,6-\mathrm{C}_{4} \mathrm{H}_{4} \mathrm{X}=\mathrm{O}$ (38)<smiles>[R]c1ccc(/C=N/NC(=O)c2ccccc2O)c(O)c1</smiles>

14a $\mathrm{R}=\mathrm{H}(35)$

14b $\mathrm{R}=3-\mathrm{CH}_{3} \mathrm{O}$ (35)

14c $\mathrm{R}=3-\mathrm{C}_{2} \mathrm{H}_{5} \mathrm{O}$ (35)

14d R=5,6- $\mathrm{C}_{4} \mathrm{H}_{4}(35)$

14e $\mathrm{R}=3,5-\mathrm{Cl}(35)$

14f $\mathrm{R}=5-\mathrm{Cl}$ (36)

$14 \mathrm{~g} \mathrm{R}=5-\mathrm{NO}_{2}(36)$

14h $\mathrm{R}=5-\mathrm{Br}$ (36)

Figure 4. Various hydrazide Schiff bases reported for preparation of dioxomolybdenum(VI) complexes. (Reference numbers are given in brackets).

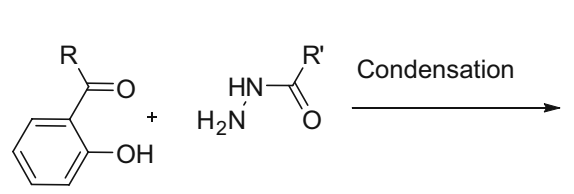

$\mathrm{R}=\mathrm{H}$ or $\mathrm{CH}_{3}$<smiles>O=C(N/N=C/c1ccc(Br)cc1O)c1nc2ccccc2s1</smiles>

16a $\mathrm{R}=\mathrm{H}(40)$ 16b $\mathrm{R}=5,6-\mathrm{C}_{4} \mathrm{H}_{4}(40)$<smiles>[R7]C(=NNC(=O)c1cc(C)[nH]n1)c1ccc(Br)cc1O</smiles>

17a $\mathrm{R}_{1}=\mathrm{H} \mathrm{R}_{2}=\mathrm{H}$ (39) 17b R $\mathrm{R}_{1}=\mathrm{H} \mathrm{R}_{2}=\mathrm{CH}_{3}$ (39)

17c $\mathrm{R}_{1}=5-\mathrm{Br} \mathrm{R}_{2}=\mathrm{H}$ (39) 17d R $=5-\mathrm{NO}_{2} \mathrm{R}_{2}=\mathrm{H}$ (39)

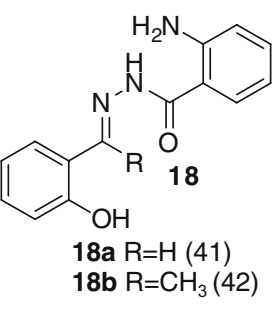

Scheme 8. Synthesis of molybdenum(VI) hydrazide Schiff base complexes.<smiles>O=C(O)c1cccc(C(=O)O)n1</smiles><smiles>[R]N(C(CO)c1ccccc1)C(c1ccccc1)c1ccccc1</smiles>

20

20a R= H (44)

20b $\mathrm{R}=\mathrm{CH}_{3}(44)$

$19(43)$
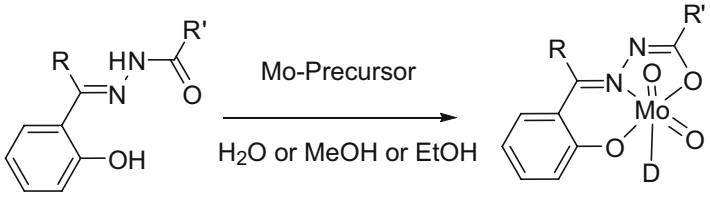

$\mathrm{R}=\mathrm{H}$ or $\mathrm{CH}_{3}$ $\mathrm{D}=$ Solvent<smiles>[R]c1ccc(/C=N/C([R])C(=O)O)c(O)c1</smiles>

21<smiles>Cc1ncc(CO)c(/N=C/Nc2ccccc2C(=O)O)c1O</smiles>

$22(11)$

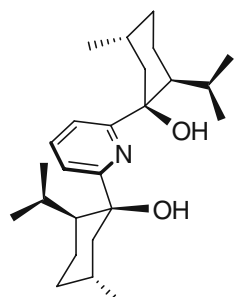

$23(45)$

21a $\mathrm{R}=\mathrm{CH}\left(\mathrm{CH}_{3}\right)_{2}$ (13)

21b $\mathrm{R}=\mathrm{CH}_{2} \mathrm{CH}\left(\mathrm{CH}_{3}\right)_{2}$ (13) 21c $\mathrm{R}=\mathrm{C}_{4} \mathrm{H}_{5} \mathrm{~N}_{2}(13)$

Figure 5. Various other tridentate ligands used for preparing dioxomolybdenum(VI) complexes. 


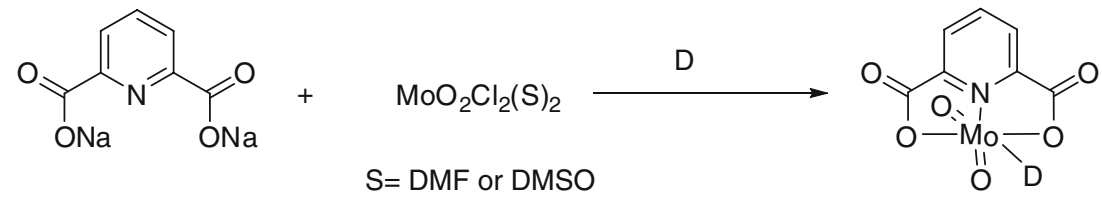

Scheme 9. Synthesis of dioxomolybdenum(VI) pyridine-2,6-dicarboxylate.

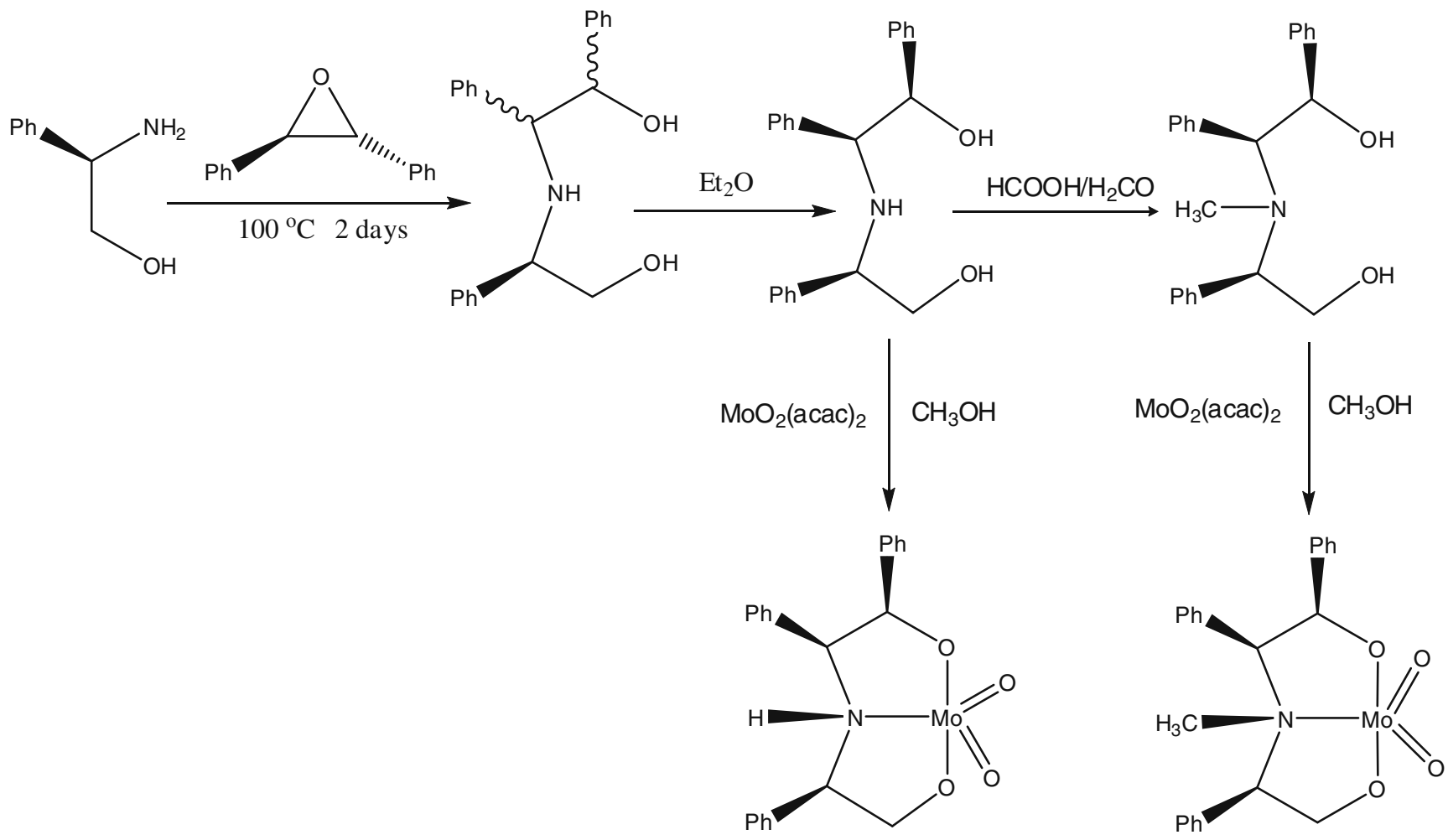

Scheme 10. Dioxomolybdenum(VI) complexes containing enantiomerically pure amino diol ligands. The structure shown here is the repeating unit of the linear oligomeric complex (see figure 2).

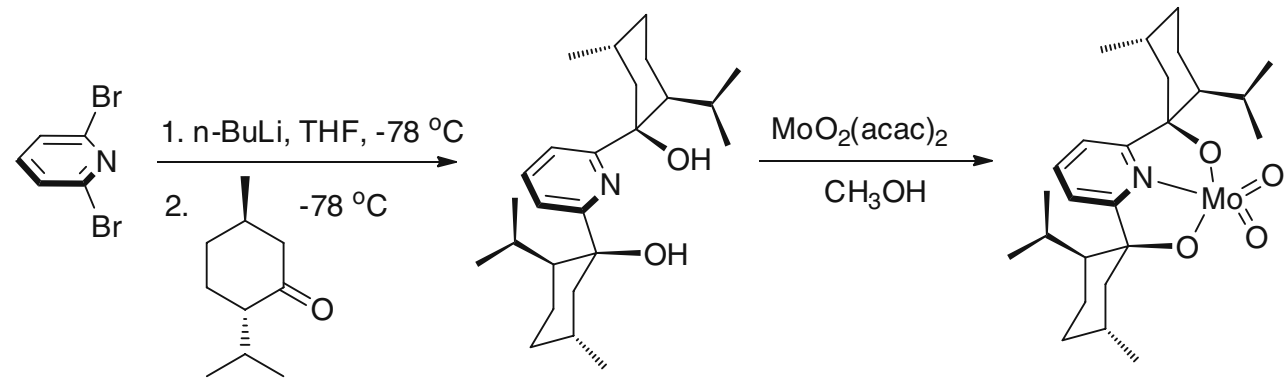

Scheme 11. Dioxomolybdenum(VI) complexes with pyridine-diol ligand. 


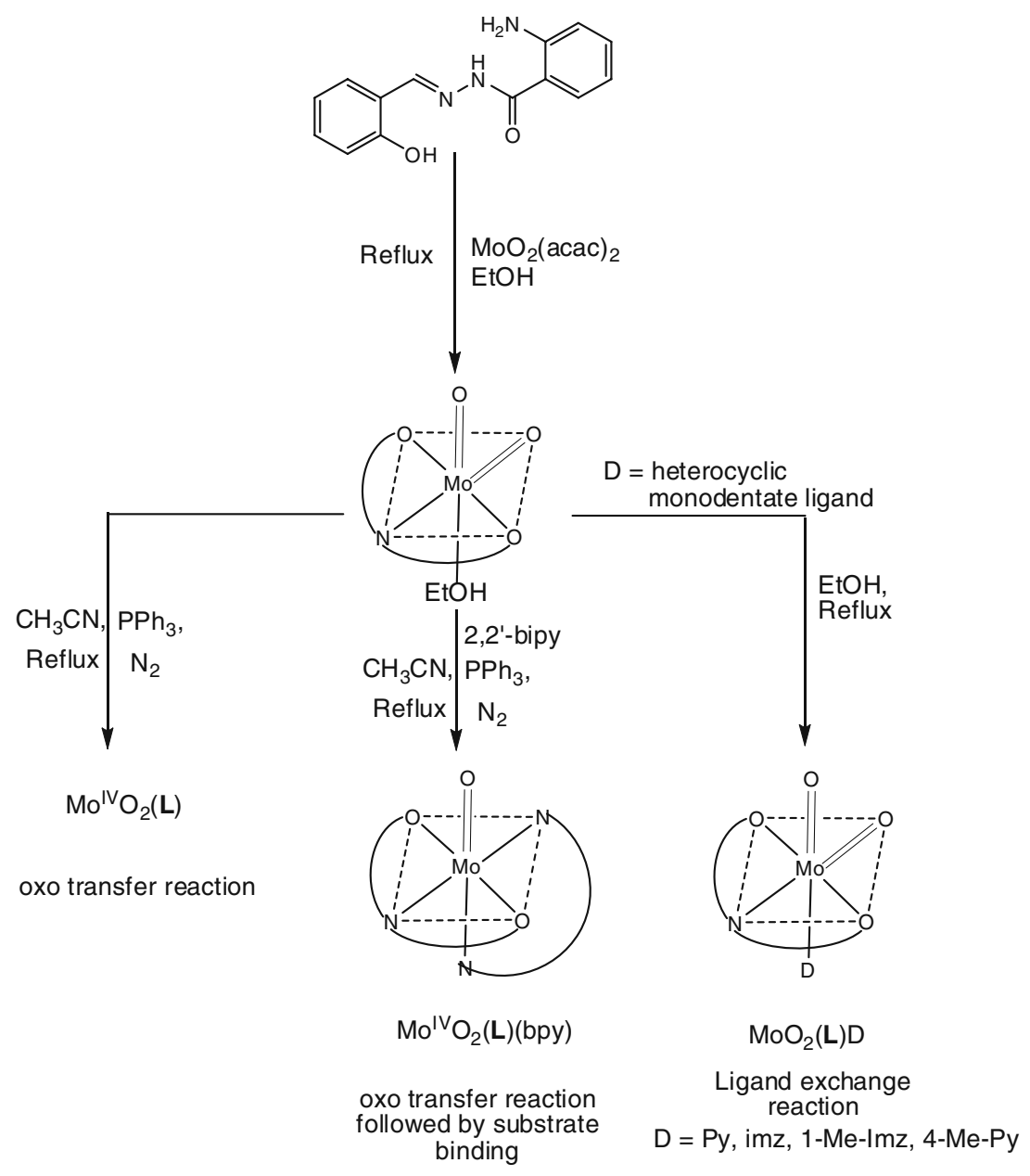

Scheme 12. Formation of oxomolybdenum(IV) from dioxomolybdenum(VI) during the oxo transfer reaction.

The amino diols are prepared by using the methodology of nucleophilic attack of required amine on epoxide. The metal centre in the complex is coordinated in a distorted octahedral geometry displaying a cisdioxo unit and two trans-alkoxo atoms. The coordination polyhedron is completed by a nitrogen atom and by a bridging oxo-oxygen atom from an adjacent unit leading to a linear polymer as shown in figure 2 . It is suggested that the linear polymeric chain connected through $\mathrm{Mo}=\mathrm{O} \cdots \cdot$. Mo bridges in solid state is most likely cleaved by the solvent molecule to form the mononuclear complex.

Bellemin-Laponnaz et al. have reported a $C_{2}$ symmetric dioxomolybdenum(VI) complex with a chiral pyridine-diol ligand derived from menthone as shown in (scheme 11). ${ }^{45}$ The NMR spectrum of the molybdenum complex showed only one set of resonance for two menthol groups on the chiral pyridine-diol ligand supporting its symmetry.
Dioxomolydenum(VI) complexes can also be prepared with Schiff bases of amino acids. ${ }^{11,13}$ The general method for the preparation of such complexes follows the same procedure as shown in (scheme 1). The Schiff base which contains phenolic, carboxylic and imine groups acts as dianionic tridentate ligand which when complexed with suitable Mo-precursor give cis-dioxo Mo(VI) complexes.

\section{Applications}

Major focus with respect to applications of cis$\mathrm{MoO}_{2}$-(ONO) type complexes have been oxo transfer reactions like epoxidation, sulfoxidation and phosphine oxidation reactions. Besides the oxidation reaction, the complexes prepared from a bisphenol ligand shown in scheme 5 along with $\mathrm{Et}_{2} \mathrm{AlCl}$ are used as catalysts for ROMP of norbornene. ${ }^{34}$ The molybdenum complex 
with Schiff base derived from 3-formyl salicylic acid and $o$-hydroxybenzylamine is supported on polymer and used as catalysts for the oxidation and oxidative bromination of organic substrates. ${ }^{46}$ In a separate line, novel bimetallic complexes have also been reported in order to study the metal-metal interaction. Some of these applications are discussed in this section.

\subsection{Oxygen atom transfer reactions}

It has been assumed for several years that the presence of sulfur atoms coordinated to molybdenum is a requisite for oxygen atom transfer reactions in order to mimic oxotransferases enzymes. However, certain molybdenum(VI) complexes of dibasic tridentate ONO ligands having no $\mathrm{S}$ center are found to oxidize a variety of tertiary phosphines, thus mimicking the active sites of oxo transfer enzymes. Although tertiary phosphines are not physiological substrates, they are the most commonly used model substrates for studying oxygen atom transfer reactions. Topich and Lyon III observed the formation of oxomolybdenum(IV) complexes during the oxo transfer process mediated by some $\mathrm{Mo}(\mathrm{VI})$ complexes. ${ }^{47}$ Boyd and Spence have reduced Mo(VI) complexes using tertiary phosphines where upon in some cases monomeric Mo(IV) and other cases $\mu$ oxo-dimolybdenum(V) compounds are formed. ${ }^{48}$ Thus, whether dimer formation is an essential characteristic of the oxotransfer reaction or not is being debated.

The $\mathrm{Mo}(\mathrm{VI})$ complexes i.e., cis- $\mathrm{MoO}_{2}(\mathbf{L})\left(\mathrm{C}_{2} \mathrm{H}_{5} \mathrm{OH}\right)$ prepared from ligands 18a or $\mathbf{1 8 b}$ react with $\mathrm{PPh}_{3}$ in acetonitrile under dry nitrogen, in presence or absence of bpy to give $\mathrm{OPPh}_{3}$ (scheme 12). The other products formed during the oxidation study are $\mathrm{MoO}(\mathbf{L})$ or $\mathrm{MoO}(\mathbf{L})$ (bpy) which support the formation of $\mathrm{Mo}(\mathrm{IV})$ intermediates during the oxotransfer process. ${ }^{41,42}$ This reaction is a good model of the oxo transfer reactions exhibited by molybdoenzymes. The Mo(VI) complexes derived from aminodiol 20 can oxidise $\mathrm{PPh}_{3}$ catalytically in DMSO. The mechanism involve formation of Mo(IV) species as intermediate as shown in scheme $13 .^{44}$

\subsection{Catalytic epoxidation}

Molybdenum complexes are considered to be very efficient catalysts for epoxidation reactions using alkyl hydroperoxide as oxidants. ${ }^{24}$ The dioxomolybdenum(VI) complexes with Schiff base, derived from tris(hydroxymethyl)amino methane and substituted salicylaldehyde show good catalytic activity (up to $100 \%$ yield) and selectivity in the epoxidation of cyclohex-

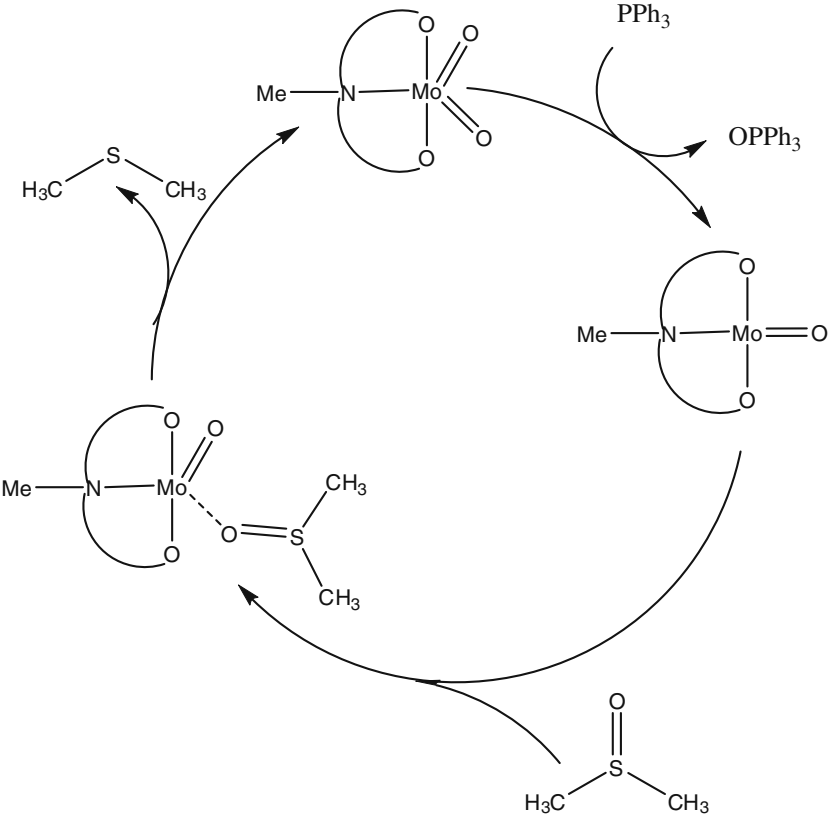

Scheme 13. Proposed mechanism for the catalytic oxo transfer reaction from DMSO to $\mathrm{PPh}_{3}$.

ene with $t$-butylhydroperoxide. Introduction of electron withdrawing group to the salicylidene ring of complex strongly increases the effectiveness of a catalyst. The initial step involved in the process is the dimerisation of the complex which reacts with the peroxide to give a mononuclear intermediate complex $\mathrm{MoO}_{2}(\mathbf{L})$ (TBHP) where peroxo oxygen is activated followed by epoxidation of the substrate (scheme 14). The sugar-based Schiff base Mo(VI) complexes prepared from ligand $\mathbf{1 0}$ show high catalytic activity for epoxidation. The enantiomeric excess up to $30 \%$ was obtained in case of cis- $\beta$-methyl styrene. ${ }^{32}$ In case of epoxidation of allylic alcohol, the Schiff base Mo(VI) complexes from amino acids induce enantiomeric excess up to $15 \% .{ }^{13}$

\subsection{Catalytic oxidation of sulfide}

The oxidation of various organic sulfides by urea hydrogenperoxide in presence of a $\mathrm{Mo}(\mathrm{VI})$ catalyst has been reported by Sheikhshoaie et al. (scheme 15). ${ }^{25}$ The formation of sulfoxide and sulfone can be well-controlled by utilizing the suitable molar ratio of oxidant and substrate. Further, this catalyst shows excellent chemoselectivity. A sulfide having double bond was also transformed into sulfoxide in good yield without affecting it. The sulfides having benzylic and phenyl substituent were selectively oxidized to their corresponding sulfoxide without undergoing oxidation at the benzylic carbon. 
$2 \mathrm{MoO}_{2}(\mathbf{L})(\mathrm{MeOH}) \stackrel{-2 \mathrm{CH}_{3} \mathrm{OH}}{+2 \mathrm{CH}_{3} \mathrm{OH}} \quad[\mathrm{MoO}(\mu-\mathrm{O})(\mathbf{L})]_{2}$

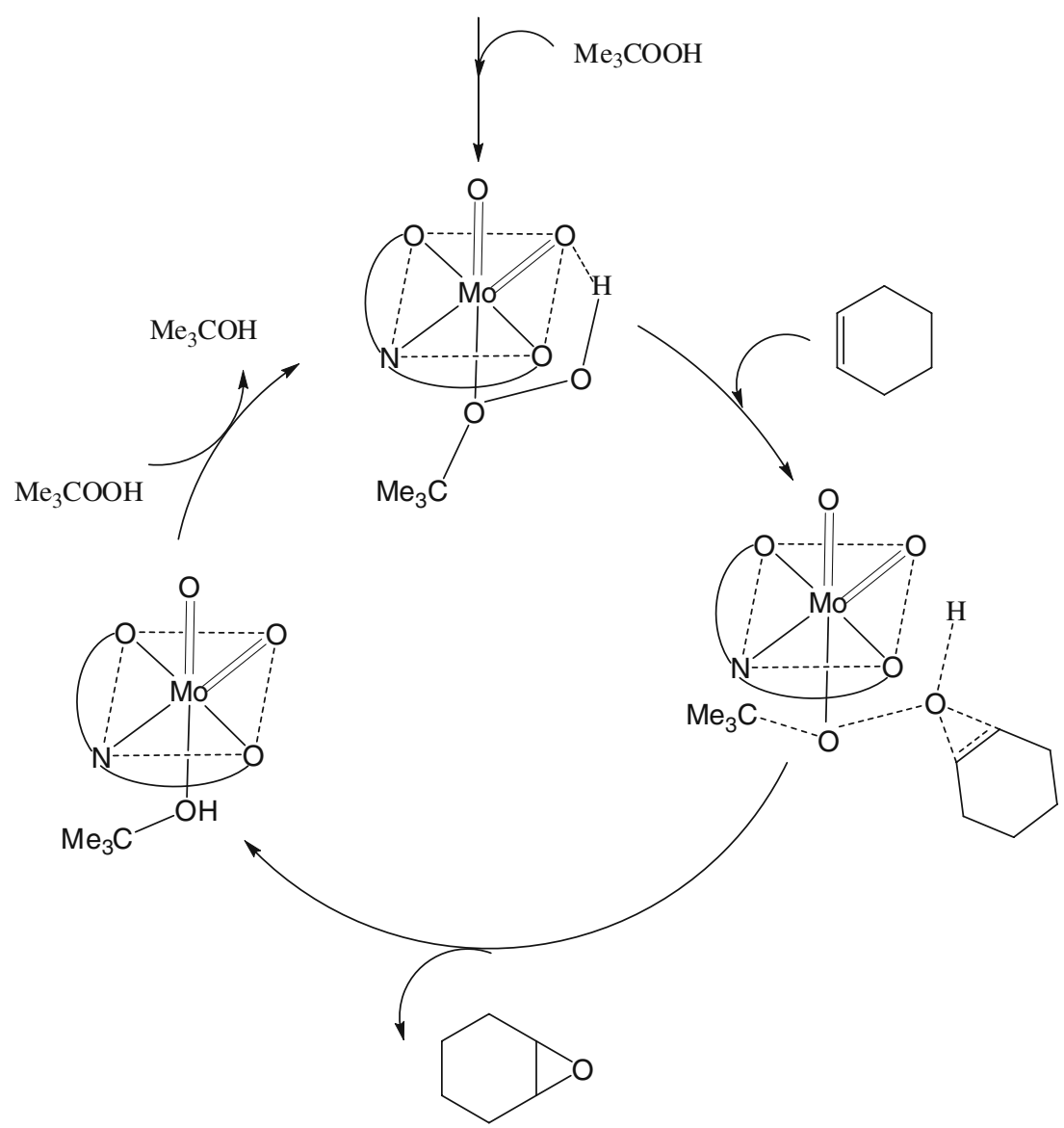

Scheme 14. Proposed mechanism for catalytic epoxidation reaction.

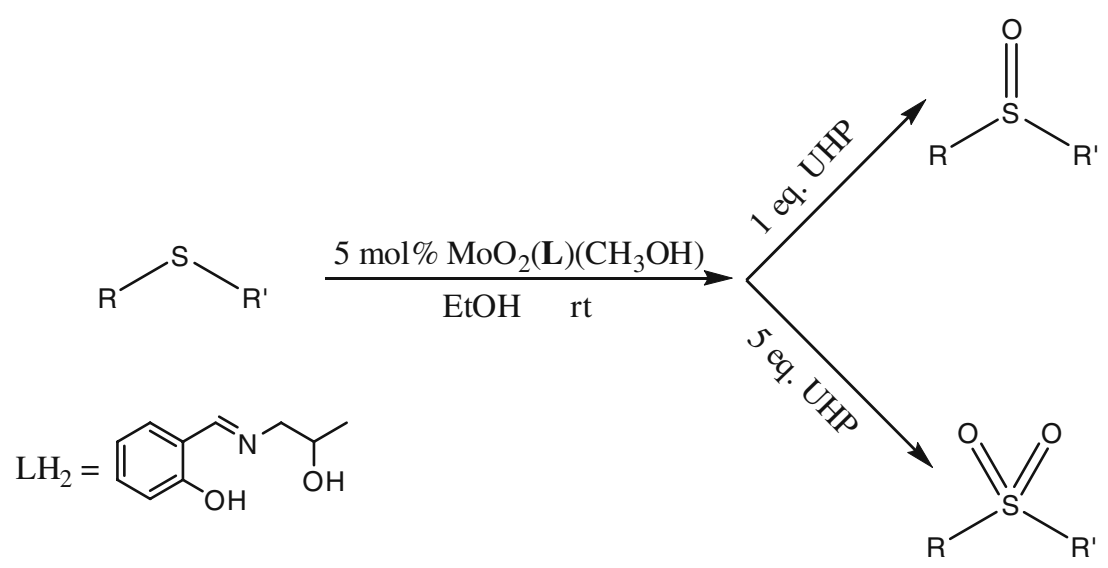

Scheme 15. Selective oxidation of sulfides to sulfoxides and sulfones. 


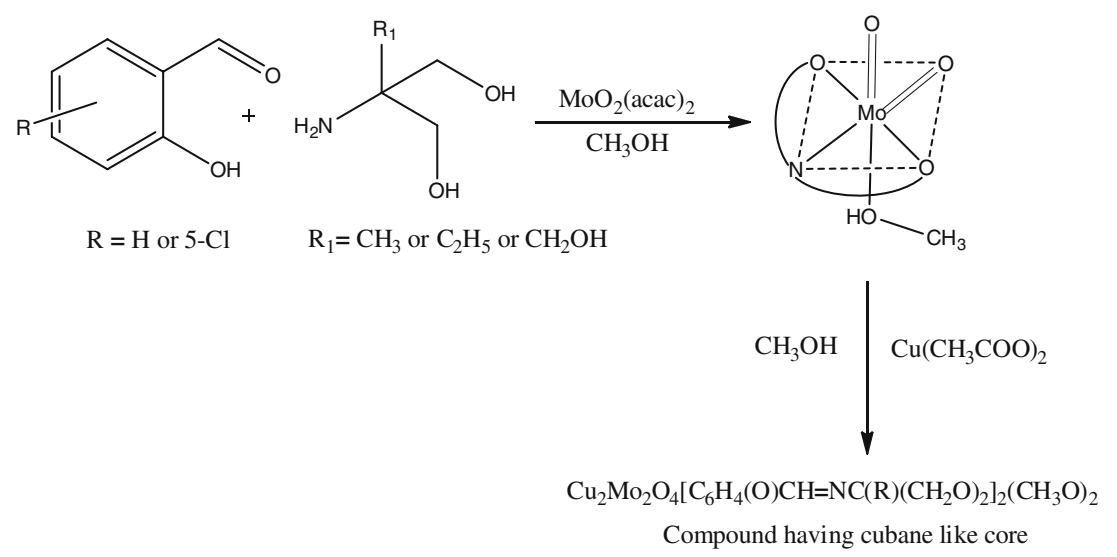

Scheme 16. Synthesis of mixed metal complex of $\mathrm{Mo}(\mathrm{VI})$ with $\mathrm{Cu}(\mathrm{II})$ ions.

\subsection{Synthesis of mixed metal complexes containing cubane like core}

Mixed metal complexes are prepared by reacting $\mathrm{MoO}_{2}(\mathbf{L})\left(\mathrm{CH}_{3} \mathrm{OH}\right)$ with copper(II) acetate aiming to study metal-metal interaction. ${ }^{49}$ Such types of structures are also found in biological systems. The uncoordinated alcoholic group of the molybdenum complexes and methanol are deprotonated followed by complexation with $\mathrm{Cu}(\mathrm{II})$ ions (scheme 16) to give a novel tetarnuclear cube like structure as shown in figure 6 .

$\mathrm{Mo}(\mathrm{VI})-\mathrm{Cu}(\mathrm{II})$ Schiff base complexes having cubane-like cores of formula $\mathrm{Cu}_{2} \mathrm{Mo}_{2} \mathrm{O}_{4}$ can be described as strongly distorted cube in which four corners are occupied by two molybdenum and two copper

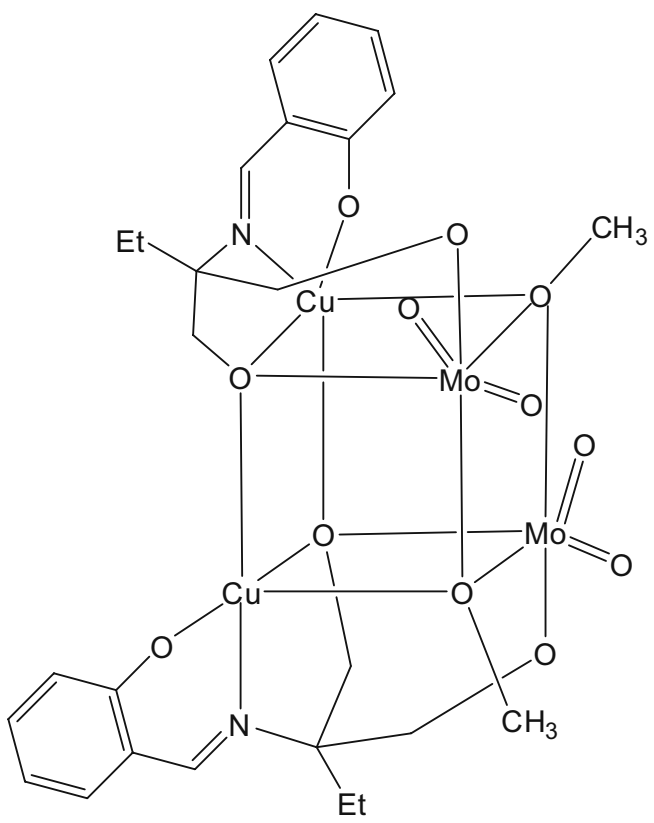

Figure 6. Molecular structure of the mixed cube like complex. atoms. The cube is completed by four oxygen atoms from the two Schiff base molecules and two methoxy ligands.

\section{Conclusion}

The chemistry of dioxomolybdenum(VI)-(ONO) type complexes is discussed in this review. The general synthesis for the preparation of complexes using Schiff base, hydrazide Schiff base and other related tridentate ligands is covered. This review also focuses on various structural properties of molybdenum complexes and the applications of some complexes particularly in oxygen transfer reactions. These complexes may act as potential catalysts for application in organic synthesis which is not yet well explored. Chiral complexes of similar formulations can be probed for affecting asymmetric synthesis. We are now paying attention to the chemistry of chiral cis- $\mathrm{MoO}_{2}(\mathrm{ONO})$ complexes.

\section{Acknowledgements}

We thank Council of Scientific and Industrial Research (CSIR), India for providing financial support (No.01 (2108)/07/EMR-II) to our research project on 'Molybdenum-based catalysts for organic transformations'.

\section{References}

1. Hille R 1996 Chem. Rev. 962757

2. (a) Grasselli R K 1999 Catal. Today 49 141; (b) Jørgensen K A 1989 Chem. Rev. 89 431; (c) Schrock R R and Hoveyda A H 2003 Angew. Chem. Int. Ed. 42 4592

3. Jeyakumar K and Chand D K 2009 J. Chem. Sci. 121 111 
4. Sanz R and Pedrosa M R 2009 Curr. Org. Synth. 6239

5. Syamal A and Maurya M R 1989 Coord. Chem. Rev. 95 183

6. Rajan O A and Chakravorty A 1979 Inorg. Chim. Acta 37 L503

7. Topich J 1980 Inorg. Chim. Acta 46 L37

8. Dey K, Maiti R K and Bhar J K 1981 Transition Met. Chem. 6346

9. Rajan O A and Chakravorty A 1981 Inorg. Chem. 20660

10. Topich J and Lyon J T III 1984 Polyhedron 355

11. Syamal A and Maurya M R 1986 Indian J. Chem. A25 1152

12. Syamal A and Maurya M R 1986 Synth. React. Inorg. Met.-Org. Chem. 16857

13. Casella L, Gullotti M, Pintar A, Colonna S and Manfredi A 1988 Inorg. Chim. Acta 14489

14. Craig J A, Harlan E W, Snyder B S, Whitener M A and Holm R H 1989 Inorg. Chem. 282082

15. Mohanty R N, Chakravortty V and Dash K C 1991 Polyhedron 1033

16. Nakajima K, Yokoyama K, Kano T and Kojima M 1998 Inorg. Chim. Acta 282209

17. Maurya M R, Jayaswal M N, Puranik V G, Chakrabarti P, Gopinathan S and Gopinathan C 1997 Polyhedron 16 3977

18. Rao C P, Sreedhara A, Rao P V, Verghese M B, Rissanen K, Kolehmainen E, Lokanath N K, Sridhar M A and Prasad J S 1998 J. Chem. Soc., Dalton Trans. 2383

19. Rao C P, Sreedhara A, Rao P V, Lokanath N K, Sridhar M A, Prasad J S and Rissanen K 1999 Polyhedron 18 289

20. Liimatainen J, Lehtonen A and Sillanpää R 2000 Polyhedron 191133

21. Kato M, Nakajima K, Yoshikawa Y, Hirotsu M and Kojima M 2000 Inorg. Chim. Acta 31169

22. Sandbhor U, Padhye S and Sinn E 2002 Transition Met. Chem. 27681

23. Zhou X, Zhao J, Santos A M and Kühn F E 2004 Z. Naturforsch. 59b 1223

24. Sui Y, Zeng X, Fang X, Fu X, Xiao Y, Chen L, Li M and Cheng S 2007 J. Mol. Catal. A: Chem. 27061

25. Sheikhshoaie I, Rezaeifard A, Monadi N and Kaafi S 2009 Polyhedron 28733

26. Topich J 1981 Inorg. Chem. 203704
27. Sobczak J M, Głowiak T and Ziółkowski J J 1990 Transition Met. Chem. 15208

28. Mondal J U, Schultz F A, Brennan T D and Scheidt W R 1988 Inorg. Chem. 273950

29. Zhang C, Rheinwald G, Lozan V, Wu B, Lassahn P-G, Lang H and Janiak C 2002 Z. Anorg. Allg. Chem. 628 1259

30. Głowiak T, Jerzykiewicz L, Sobczak J M and Ziółkowski J J 2003 Inorg. Chim. Acta 356387

31. Sah A K, Rao C P, Saarenketo P K, Wegelius E K, Kolehmainen E and Rissanen 2001 Eur. J. Inorg. Chem. 2773

32. Zhao J, Zhou X, Santos A M, Herdtweck E, Romão C C and Kühn F E 2003 Dalton Trans. 3736

33. Cindrić M, Strukan N, Vrdoljak V, Kajfež T and Kamenar B 2002 Z. Anorg. Allg. Chem. 6282113

34. Lehtonen A and Sillanpää R 2005 Polyhedron 24257

35. Syamal A and Kumar D 1982 Transition Met. Chem. 7 118

36. Syamal A and Kumar D 1982 Indian J. Chem. A21 534

37. Prabhakaran C P and Nair B G 1983 Transition Met. Chem. 8368

38. Syamal A and Maurya M R 1986 Transition Met. Chem. 11235

39. Gupta S, Barik A K, Pal S, Hazra A, Roy S, Butcher R J and Kar S K 2007 Polyhedron 26133

40. Syamal A and Maurya M R 1986 Transition Met. Chem. 11201

41. Dinda R, Sengupta P, Ghosh S, Mayer-Figge H and Sheldrick W S 2002 J. Chem. Soc., Dalton Trans. 4434

42. Dinda R, Sengupta P, Ghosh S and Sheldrick W S 2003 Eur. J. Inorg. Chem. 363

43. Arnáiz F J, Aguado R, Pedrosa M R, Cian A D and Fischer J 2000 Polyhedron 192141

44. Barbaro P, Belderrain T R, Bianchini C, Scapacci G and Masi D 1996 Inorg. Chem. 353362

45. Bellemin-Laponnaz S, Coleman K S, Dierkes P, Masson J-P and Osborn J A 2000 Eur. J. Inorg. Chem. 1645

46. Maurya M R, Kumar U and Manikandan P 2006 Dalton Trans. 3561

47. Topich J and Lyon J T III 1984 Inorg. Chem. 233202

48. Boyd I W and Spence J T 1982 Inorg. Chem. 211602

49. Kessissoglou D P, Raptopoulou C P, Bakalbassis E G, Terzis A and Mrozinski J 1992 Inorg. Chem. 314339 